\title{
ORIGINALS
}

\section{Size, Lipid and Enzyme Content of Isolated Human Adipocytes in Relation to Nutritional State}

\author{
A. Englhardt, F.A. Gries, H. Liebermeister and K. Jahnke
}

\author{
2. Medizinische Universitätsklinilk und Diabetes-Forschungsinstitut an der Universität Düsseldorf \\ (Prof. Dr. K. Oberdisse)
}

Received: October 29, 1970, accepted: January 14, 1971

Summary. The following parameters have been determined or calculated in isolated adipocytes from subcutaneous human adipose tissue from normal weight and obese subjects, obtained during surgical interventions or from volunteers who received local anaesthesia. Mean cell diameter, mean cellular lipid content, mean fat cell volume, and volume of lipid-free space. In fat cell extraets the activities of the following enzymes were measured: Glucose-6-phosphate-dehydrogenase, Phosphoglucomutase, Fructose-6-phosphatekinase, Hexosephosphate-isomerase, Aldolase, Glycerolaldehyde-phosphate-dehydrogenase, Phosphoglycerate-kinase, Pyruvate-kinase, Lac. tate-dehydrogenase. - In subjects with more than $50 \%$ overweight, the mean fat cell diameter was significantly increased. Mean fat cell volume calculated from fat cell diameter increased from $376 \pm 115 \mathrm{~mm}^{3} \times 10^{-6}$ in normal weight to $799+99.5 \mathrm{~mm}^{3} \times \overrightarrow{10}^{-6}$ in obesity. - In obese subjects the mean lipid content of individual adipocytes was twice as high as in normal weight subjects. The lipidfree residual space was also significantly larger in obesity. Nevertheless, this lipid-free space occupied a significantly smaller percentage of a defined fat cell mass in obese than in normal weight subjects. - Related to triglycoride content, the activities of HIM, G6PDH, and Aldolase were significantly reduced in adipocytes of subjects with more than $50 \%$ overweight, in a second series this was true for LDH also. There were significant negative correlations of the logarithms of these enzymes to the logarithm of overweight. There was an increased mean absolute enzyme content in adipocytes of obese subjects compared with those of normal weight persons. However, this increase was significant for LDH and HTM only. It is not certain that the enzyme pattern in the fat cells of obese subjects is related to the increase in cell volume. When related to a defined fat cell mass after correction for extra-cellular space, diminished activities for Aldolase, G6PDH, HIM, and $\mathrm{LDH}$ were found.

Taille, contenu de lipides et d'enzymes de cellules adipeuses humaines isolées en relation avec le degré de nutrition

Résumé. Les mesures suivantes ont été faites sur des cellules adipeuses de tissu humain sous-cutané provenant de sujets obèses et de sujets normaux: diamètre moyen des cellules, contenu lipidique moyen des cellules, volume moyen des cellules adipeuses et volume de l'espace sans lipides. Le tissu a été obtenu à l'occasion d'opérations chirurgicales ou chez des volontaires sous anesthésie locale. Dans des extraits de cellules adipeuses ont été mesurées les activités des enzymes suivants: glucose-6-phosphate déshydrogenase, phosphoglucomutase, fructose-6-phosphate kinase, hexosephosphatisomerase, aldolase, glycerinaldehydphosphate déshydrogenase, phosphoglycerate kinase, pyruvate kinase, lactate déshydrogenase. - Lo diamètre moyen des cellules adipeuses est significative- ment augmenté chez les sujets obèses d'un poids excédant $\mathbf{5 0} \%$ de la normale. Le volume moyen des cellules adipeuses calculé d'après le diamètre des cellules adipeuses est passé d'une valeur de $376+115 \times 10^{-6} \mathrm{~mm}^{3}$ chez des sujets normaux à une valeur de $799 \pm 99.5 \times 10^{-6} \mathrm{~mm}^{3}$ chez des sujets obèses. - $\mathrm{L} e$ contenu lipidique moyen d'une cellule adipeuse isolée est deux fois plus important que chez les sujets normaux. De même, l'espace cellulaire sans lipides est significativement accru. Mais le pourcentage de l'espace sans lipides par rapport à une masse de cellules adipeuses définie est significativement moins élevé chez les sujets obèses que chez les normaux. - Par rapport aux triglycerides, les activités des enzymes HIM, G6PDH et aldolase dans les cellules adipeuses de sujets ayant un excédent de poids supérieur à $50 \%$ sont plus réduites et de même dans une deuxième série, y compris LDH. Les logarithmes des activités de ces enzymes et ceux de l'excédent de poids sont en corrélation négative de façon significative. Le contenu moyen absolu des enzymes des cellules adipeuses chez les sujets obèses s'est montré supérieur par rapport à celui des cellules des sujets de poids normaux. L'augmentation n'est significativement élevée que pour LDH et HIM. Le comportement des enzymes dans les cellules adipeuses de sujets obèses n'est pas en relation avec l'augmentation du volume de la cellule adipeuse. Au contraire, les activités se montrent plus réduites pour les enzymes G6PDH, HIM et LDH, si les valeurs sont mises en rapport avec une masse de cellules adipeuses définie après la correction de l'espace extracellulaire.

Über Größe, Lipid- und Enzymgehalt isolierter menschlicher Fettzellen in Abhängigkeit vom Ernährungszustand

Zusammenfassung. An isolierten Fettzellen aus subcutanem menschlichen Fettgewebe Normgewichtiger und Adipöser, das bei chirurgischen Operationen gewonnen oder bei Freiwilligen in Lokalanästhesie exzidiert wurde, wurden folgende Parameter gemessen bzw. berechnet: mittlerer Zelldurchmesser, mittlerer Lipidgehalt der Zellen, mittleres Fettzellvolumen und Volumen des lipidfreien Raumes. In Fettzellextrakten wurden die Aktivitäten folgender Enzyme gemessen: Glucose-6-Phosphatdehydrogenase, Phosphoglucomutase, Fructose-6phosphatkinase, Hexosephosphatisomerase, Aldolase, Glycerinaldehydphosphatdehydrogenase, Phosphoglyceratkinase, Pyruvatkinase, Lactatdehydrogenase. - Der mittlere Fettzelldurchmesser war bei Fettsüchtigen mit einem Übergewicht von mehr als $50 \%$ signifikant erhöht. Das aus dem Fettzelldurchmesser errechnete mittlere Fettzellvolumen stieg von einem Wert von $376+115 \times$ $10^{-6} \mathrm{~mm}^{3}$ bei Normgewichten auf $799+99.5 \times 10^{-6} \mathrm{~mm}^{3}$ bei Fettsüchtigen. - Der mittlere Lipidgehalt einer einzelnen Fettzelle war bei Fettsiichtigen mehr als doppelt so groß als bei Normgewichtigen. Auch der lipidfreie Restraum war bei Fettsiichtigen signifikant größer. Der pro- 
zentuale Anteil dieses lipidfreien Raumes an einer definierten Fettzellmasse war aber bei Übergewichtigen signifikant kleiner als bei Normgewichtigen. - Bezogen auf Triglyceride waren die Aktivitäten der Enzyme HIM, G6PDH und Aldolase in den Fettzellen der Probanden mit mehr als $50 \%$ Ủbergewicht signifikant herabgesetzt, in einer zweiten Serie auch LDH. Fs bestanden signifikante negative Korrelationen der Logarithmen dieser Enzyme zum Logarithmus des Übergewichtes. Der mittlere absolute Enzymgehalt der Fettzellen Fettsüchtiger wurde gegenüber demjenigen der Zellen Normgewichtiger erhöht gefunden. Der Anstieg war aber nur für LDH und HIM signifikant. Das Verhalten der Enzyme in den Fettzellen Adipöser stand nicht sicher in Relation zur Volumenvergrößerung der Fettzelle. Im Gegensatz dazu ergaben sich herabgesetzte Aktivitäten für die 4 untersuchten Enzyme Aldolase, G6PDH, HIM und LDH, wenn die Werte auf eine definierte Fettzellmasse nach Korrektur für den extrazellulären Raum bezogen wurden.

Key-words : Fat cells, obesity, enzymes.
The composition of adipose tissue in obese persons has been subject to many investigations. Reports of several groups have agreed that growth of adipose tissue during weight-gain is the result not only of an increased volume of the fat cell itself, but also due to formation of new adipocytes. Bjurulf found a definite positive correlation between the thickness of adipose tissue, cell-number, and cell-size (Bjurulf 1959) [1a]. In hyperglycaemic obese mice Hausberger and Hausberger [11] obtained the same results. In isolated human adipocytes Preiss [20] and coworkers described a definite positive correlation between fat cell size and body weight up to an overweight of $70 \%$; in gross obesity the number of cells increases. By determining DNA and measuring fat cell sizes, Liebelt [15] was also able to show that the volume of the adipocyte remained constant at a certain overweight, and that further growth of adipose tissue was the result of the formation of new fat cells.

Since a small increase in cell diameter will already augment the storage capacity considerably (the cell volume changing with the cube of the radius), questions arise concerning the morphological structure and the capacity of the enlarged adipocyte. Up to now, investigations have led to contradictory results. Pawan and Clode [19] as well as Entenman et al. found diminished amounts of protein and lipid in adipose tissue of obese people, whereas Forbes et al. [10] and Mitchell et al. [17] described elevated protein contents. These discrepancies are probably methodological in origin. Diverging amounts of connective and vascular tissue in the fat pads and the presence of young proteinpoor adipocytes should be considered. Prior investigations of human adipose tissue and isolated fat-cells have demonstrated that about half of the soluble protein of the total tissue is not derived from adipocytes but from unspecific accompanying tissue (Englhardt et al. [6]). Changes in the morphological composition of the tissue can therefore lead to wrong conclusions. For this reason, further studies were performed on isolated fat cells.

The investigations described below deal with the composition of isolated human adipocytes of obese and normal-weight persons. Fat cell size and lipid content were determined to obtain data on the extent of cell growth and lipid storage in obesity. From evaluations of enzyme activities we expected orientation concer- ning the amount of active enzyme protein in the plasmatic compartment of the cells. Since isolated fat cells can only be kept stable in albumin-containing solutions, the assessment of total protein contents was not possible.

The following parameters were determined in isolated human adipocytes: fat cell diameter and lipid content and the activities of 9 enzymes of glycolysis and hexose-monophosphate-shunt (G6PDH, F6PK, PG/M, HIM, ALD, GAPDH, PGK, PK, LDH).

\section{Methods}

Specimens of human subcutaneous adipose tissue, taken from the abdominal region, were investigated. About $1 \mathrm{~g}$ of tissue was obtained from each of 35 subjects at the beginning of surgical interventions. Patients with malignomas, acute inflammatory processes, and metabolic diseases were excluded. Further samples of adipose tissue were excised from the lower left abdominal region of 20 healthy volunteers with local anaesthesia $(0.5 \%$ Novocaine).

All subjects had been fasting for $14-20 \mathrm{~h}$ prior to excision of the tissue. All in-patients were kept in bed during this period. The out-patients had rested for at least $1 \mathrm{~h}$ before the intervention. Immediately after excision the tissue samples were transferred into Krebs-RingerBicarbonate buffer, pH 7.4 (KRB-buffer) at $37^{\circ} \mathrm{C}$.

Preparation of the fat cells

No later than $30 \mathrm{~min}$ after excision pieces of adipose tissue of about $20-30 \mathrm{mg}$ were prepared. For the release of adipocytes, tissue pieces of about $500 \mathrm{mg}$ were incubated in plastic vessels according to the procedure described by Rodbell. The incubation medium contained: $3 \mathrm{ml}$ of KRB-buffer with $100 \mathrm{mg} / 100 \mathrm{ml}$ of glucose, $4 \mathrm{~g} / 100 \mathrm{ml}$ of human albumin and $10 \mathrm{mg}$ of collagenase. Incubation in the Warburg apparatus at $37^{\circ} \mathrm{C}$ at a vibration rate of $80 / \mathrm{min}$ for $60-75 \mathrm{~min}$. The incubation procedure was interrupted at $45 \mathrm{~min}$ and larger pieces of connective tissue were removed with small forceps. An almost complete release of fat cells was obtained after $60-75 \mathrm{~min}$. The contents of 2 vessels were mixed in a plastic centrifuge tube and centrifuged for one minute at ca. $100 \times g$. The medium was removed and the fat cell layer washed 4 times with $10 \mathrm{ml}$ of fresh KRB-buffer at $\mathrm{pH} 7.4$.

\section{Preparation of extracts}

After centrifugation the entire cell layer of one tube was transferred into a homogenization vessel and the volume determined. Extraction medium (50 mM Triethanolamine buffer), pH 7.4 with $5 \mathrm{mM}$ Na-EDTA (sodiumsalt of ethylenediamine tetraacetic acid) was added at a proportion of $1: 5$ or $1: 10$. Thereafter the suspensions were homogenized under refrigeration $\left(0\right.$ to $\left.+4^{\circ} \mathrm{C}\right)$ for 
$4 \times 30 \mathrm{sec}$ in the Ultraturrax. Thereafter 2 samples of 0.1 $\mathrm{ml}$ each were removed from the homogenate for determination of triglycerides. The rest of the homogenate was spun down for $30 \mathrm{~min}$ at $2-4^{\circ} \mathrm{C}$ in the ultracentrifuge (Spinco L 30) at $98000 \times g$. To obtain clear extracts after spinning, the centrifuge tubes were perforated at their base with a V2 A steel-cannula, the extract collected and kept in ice-water until examined.

\section{Deternination of fat cell size}

Using Silicon-fat and a siliconized cover-glass a moist chamber was set up on a microscopic slide. An aliquot of washed cells was stained by adding methylene-blue to the buffer (KRB-buffer with albumin v.s.) and dispersed uniformly by stirring. An aliquot of this suspension was transferred into the moist chamber and ensured that the cells moved freely. The cell diameter of at least 100 cells with intact plasma space and nucleus was measured under a microscope. Following the usual procedure with RBC's the mean cell diameter was determined by establishing a Price-Jones' type curve and was expressed in micrometers.

\section{Analyses}

The modification of the method by Eggstein and Kreutz [3] described by Jahnke and Herberg [13] was used for the determination of triglycerides as glyceride-glycerol. Enzyme activities were measured using optical tests:

Activities of the following enzymes were evaluated G6PDH, F6PK, PG/M, HIM, ALD, GAPDH, PK, PGK, LDH. Instructions of Bücher, Pette and Luh [2] with mo. difications for adipose tissue. Optimal reaction conditions for extracts from fat cells were determined in preliminary experiments. Techniques and methodical details have been described earlier (Englhardt et al. [5]). The extracellular water-space of fat cell layers was determined by addition of $\mathrm{D}$-Sorbitol $-\mathrm{U}{ }^{14} \mathrm{C}$ following a procedure which Crofford and Renold [4] introduced for similiar studies in adipose tissue. A detailed description of this method has been given earlier (Englhardt et al. [6]).

\section{Calculations}

Mean fat cell volume was calculated from the fat cell diameters assuming a spherical shape of the adipocyte. ${ }^{1}$

The size of the lipid space of a fat cell layer was determined in the following manner:

The lipid content was regarded as equal to that of triglycerides since Hirsch stated that $99 \%$ of human fat cell lipids are triglycerides. For calculating molar weight units an empirical molecular weight of 885 was assumed. To calculate the volume of fat cell lipids from these data, it was necessary to determine the specific weight. This was done by extracting the lipids from adipose tissue samples of 10 healthy control subjects following the procedure described by Folch [9]. With a standardized microlitre pipette samples were taken from these extracts and weighed. The mean size of the lipid space of an individual adipocyte was calculated from the total lipid space of a defined volume of the fat cell layer (correcting for its content of extracellular fluid) and the number of fat cells present in this layer. The size of the plasma space (lipidfree-space) could be calculated from the volume of the fat cell layer minus the volume of its lipid space. The mean lipid-free space of an individual adipocyte was calculated from the mean fat cell volume minus mean size of its lipid space.

Enzyme activities were indicated as $u$ mol substrate metabolized $/ \mathrm{min} /(\mathrm{mU})$. The following data were used as a

1 This value was used to calculate the number of cells in a defined empacted fat cell layer. The true volume of this fat cell layer can be calculated by subtracting the volume of extracellular fluid it contains. reference system: 1 . True fat cell volume. 2. Triglyceride contents in mmol. 3. Mean volume of an individual adipocyte. 4. Mean volume of lipid-free space of an individual adipocyte.

The weight of all subjects was calculated in \% of normal weight according to Broca, and three groups established: Group I (normal weight): $-10 \%$ to $+10 \%$, Group II (moderately obese): $+11 \%$ to $+50 \%$ overweight, Group III (markedly obese) more than $+50 \%$ overweight. Arithmetical means and standard deviations were calculated for each of these 3 groups. The significance of differences of means for these groups was evaluated using the $t$-test for nonpaired data. The data for fat cell diameter, fat cell volume, lipid space and lipid-free space were compared for groups I and III only.

\section{Reagents}

For storage, transport and preparation of the adipose tissue samples a modified Krebs-Ringer-Bicarbonatebuffer was used (composition see Englhardt et al. [5]). Buffer was gassed in the usual way with $95 \% / 5 \% \quad \mathrm{O}_{2} / \mathrm{CO}_{2}$ and used under this gas-phase, $\mathrm{pH}$ 7.4.

Collagenase from $\mathrm{Cl}$. histolyticum was obtained from Worthington Biochemical Corp., Freehold, N.J., first ammonium sulphate fraction as described by Mandl [15].

Albumin purissime was obtained from the Behring Werke. Stated degree of purity $100 \%$. Glycerol content $0.55 \mu \mathrm{mol} / \mathrm{g}$, stated content of non-esterified fatty acids $6.7 \mu \mathrm{mol} / \mathrm{g}$. Glucose p.a. purissime for bacteriological purposes (Merck) was stored in the desiccator and with. drawn under sterile conditions. Glucose levels in the buffer were measured enzymatically with Hexokinase and G6PDH.

For details concerning substrates, auxiliary enzymes and coenzymes for the determination of enzyme activities (see Englhardt et al. [5]).

\section{Results}

\section{Fat cell size and fat cell volume.}

The determination of the diameters of adipocytes obtained from normal weight and overweight subjects confirmed the results published by Preiss et al. [20]. In subjects of normal weight these authors found a mean cell diameter of $96 \mu$ and an increase in diameter correlated with body weight up to $140 \mu$ in obesity. In our series the mean cell diameter for subjects of normal weight was $88.5 \pm 9.8 \mu$, and $115 \pm 4.3 \mu$ for obese subjects whose overweight varied from $+50 \%$ to $+175 \%$. Differences between the two groups were significant. Fat cell volume increased from $376+115 \mathrm{~mm}^{3} \times 10^{-6}$ to $799 \pm 99.5 \mathrm{~mm}^{3} \times 10^{-6}$. This represents a gain in total body fat to about twice the initial value, if subcutaneous adipose tissue were representative for total fat tissue. If one further assumes that adipose tissue accounts for about $19 \%$ of total weight (Morse and Soeldner [18]), this would mean that a hypothetical subject of $70 \mathrm{~kg}$ increases his weight to $98 \mathrm{~kg}$ which would correspond to an overweight of about $40 \%$. Since overweight in the group of obese subjects with enlarged cells was higher than $+50 \%$ in every case, the increased amount of adipose tissue cannot be explained by the gain in volume of fat cells only. We have to assume an additional formation of fat cells (Table 1 ). 
Lipid content and lipid-free space of adipocytes

The space occupied by lipid storage in isolated fat cells of normal weight subjects has a mean size of $771 \pm 78 \mu \mathrm{l} / \mathrm{ml}$ fat cell volume (corr.), i.e. $77.1 \%$ of total volume. It was significantly higher in obese people $(851 \pm 84 \mu \mathrm{l} / \mathrm{ml}$ fat cells, corr. $)$, i.e. $85.1 \%$. In individual cells this corresponded to $289+90.7 \mathrm{~mm}^{3} \times 10^{-6}$ in normal weight subjects and to $682 \pm 114 \mathrm{~mm}^{3} \times 10^{-6}$ in obesity. The amount of lipid in adipocytes of obese subjects therefore has increased more than twofold. The lipid-free space of the individual fat cell, calculated by subtracting lipid space from cell volume, was also significantly higher in obesity $\left(117 \pm 61 \mathrm{~mm}^{3} \times 10^{-6}\right)$ than in normal weight $\left(86 \pm 7.7 \mathrm{~mm}^{3} \times 10^{-6}\right)$. Expressed as percent of the volume of true fat cell mass significantly lower in obese subjects than in normal weight persons. This confirmed the results of the first series. Moreover, the activity of LDH was significantly reduced, whereas this difference was not significant in the first series. These negative differences disappeared completely, if the data were calculated as mean enzyme content per individual cell. Now, in agreement with the increased volume of the adipocyte in obesity, all 4 enzymes showed higher activities. However, this increase was significant for LDH and HIM only (Table 3).

The evaluation merely takes into account the total enzyme content of the cell without regarding its size. In addition the data were therefore related to the lipidfree space of the cell mass. These results correspond to

Table 1. Investigations concerning fat cell size, fat cell volume, lipid content and size of lipid-free residual space in isolated human adipocytes of normal weight and obese subjects. Fat cell lipids determined as triglycerides 1 ml fat cell mass and lipid content of the individual adipocyte

\begin{tabular}{|c|c|c|c|c|c|c|c|}
\hline & $n$ & $\begin{array}{l}\text { Lipid space } \\
\mathrm{ml} / \mathrm{ml} \\
\text { fat-cell mass } \\
\text { (corr.) }\end{array}$ & $\begin{array}{l}\text { Lipid space/ } \\
\text { cell } \\
\mathrm{mm}^{3} \times 10^{-6}\end{array}$ & $\begin{array}{l}\text { Lipid-free } \\
\text { space } \mathrm{ml} / \mathrm{ml} \\
\text { fat-cell mass } \\
\text { (corr.) }\end{array}$ & $\begin{array}{l}\text { Lipid-free } \\
\text { space/cell in } \\
\mathrm{mm}^{3} \times 10^{-6}\end{array}$ & $\begin{array}{l}\text { Mean cell } \\
\text { diameter } \mu\end{array}$ & $\begin{array}{l}\text { Mean cell } \\
\text { volume } \\
\mathrm{mm}^{3} \times 10^{-6}\end{array}$ \\
\hline $\begin{array}{l}\text { Normal } \\
\text { weight } \\
\text { subjects }\end{array}$ & 10 & $\begin{array}{c}0.771 \\
\pm 0.078 \\
\quad p<0.02\end{array}$ & $\begin{array}{l}289 \\
\pm \quad 90.7 \\
\quad p<0.05\end{array}$ & $\begin{aligned} & 0.229 \\
& \pm 0.077 \\
& p<0.02\end{aligned}$ & $\begin{array}{l}86 \\
\pm \quad 7.7 \\
\quad p<0.025\end{array}$ & $\begin{array}{l}88.5 \\
+\quad 9.8 \\
p<0.001\end{array}$ & $\begin{aligned} & 376 \\
& \pm 115 \\
& p<0.001\end{aligned}$ \\
\hline $\begin{array}{l}\text { Obese } \\
\text { subjects }\end{array}$ & 16 & $\begin{array}{r}0.851 \\
\pm 0.084\end{array}$ & $\begin{array}{r}682 \\
\pm 114\end{array}$ & $\begin{array}{r}0.149 \\
\pm 0.086\end{array}$ & $\begin{array}{r}117 \\
\pm \quad 61\end{array}$ & $\begin{array}{r}115 \\
\pm \quad 4.9\end{array}$ & $\begin{array}{l}799 \\
\pm \quad 99.5\end{array}$ \\
\hline
\end{tabular}

(corr.) this lipid-free space occupied a significantly smaller proportion of true fat cell mass in obesity $(14.9 \%)$ than in normal weight $(22.9 \%$ ) (Table 1$)$.

Enzymatic activity of glycolysis and the hexosemono. phosphate shunt in extracts from fat cells

The following enzymes were measured in extracts from fat cells of 35 subjects: G6PDH, F6PK, ALD, PG/M, HIM, GAPDH, PGK, and LDH. In the fat cells from group III (see methods), the activities of the enzymes F6PK, G6PDH, ALD, and HIM, calculated per mmol triglycerides (Glyceride-Glycerol), were significantly lower than in those from group I and II. Moreover, the activity of $\mathrm{PG} / \mathrm{M}$ was significantly reduced in group III compared with group II (Fig. $1-3)$. There was a negative linear correlation of the logarithm of activity of G6PDH, Aldolase and HIM to the logarithms of overweight. For these 3 enzymes the difference of the regression coefficient against zero was highly significant (Table 2).

In a second series of 10 normal weight subjects and 16 obese subjects with an overweight of $+51 \%$, the activities of the following enzymes were determined: G6PDH, HIM, Aldolase and LDH. Several reference systems were used during evaluation. Based on triglyceride content the activities of 3 enzymes were
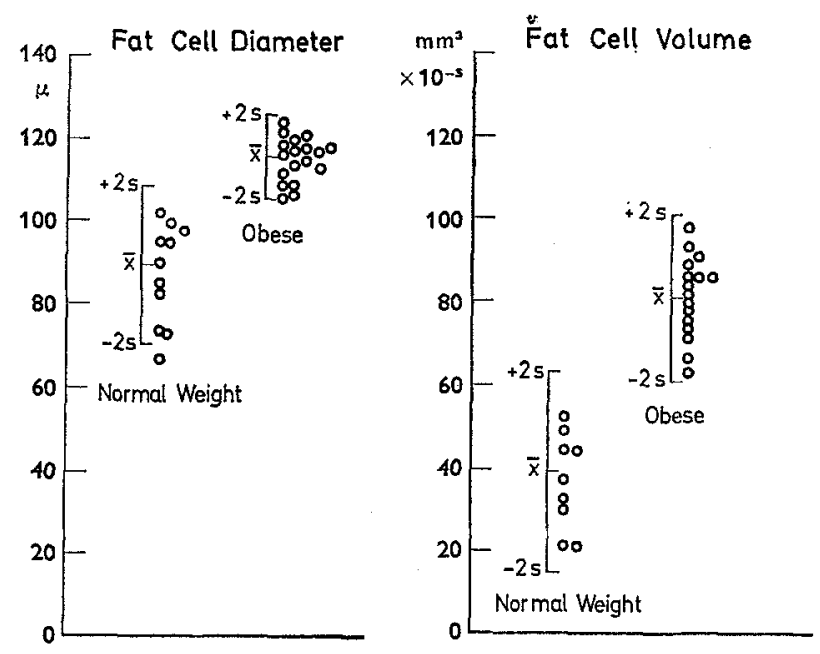

Fig. 1. Mean cell diameter and mean cell volume of isolated human adipocytes from normal weight and obese subjects. $\bar{x} \pm 2 \mathrm{~s}$ for fat cell diameter in $\mu$, for fat cell volume in $\mathrm{mm}^{3} \times 10^{-5}$

enzyme concentrations present in the plasma of fat cells. LDH and HIM were also found elevated with this procedure, but the differences were not significant, possibly because the variance of the size of the socalled lipid-free space is relatively marked. 


\section{Discussion of Results}

The data show that the change in shape the adipocyte undergoes during increase of the fat mass also leads to changes in its chemical composition. By the enlargement of these cells their lipid content is not only changed in absolute terms, but also on a percentage basis. These results therefore confirm, as was to be expected, that more lipids are stored during overeating. This fact has been observed frequently in animal ex- periments. In this case we would have to assume that the increase in cell size is caused exclusively by the augmentation of its lipid content. This necessarily would have to induce a reduction of its content of metabolites and proteins which are localized in the lipid-free space of the cell. The experimental data gained during this series of investigations showed however, that the changes which occur in the adipocyte during an increase of the fat mass are not satisfactorily explained by this hypothesis. The calculation of the

Lipid Space of Isolated Fat Cells

Lipid Space of Isolated Fat Cells
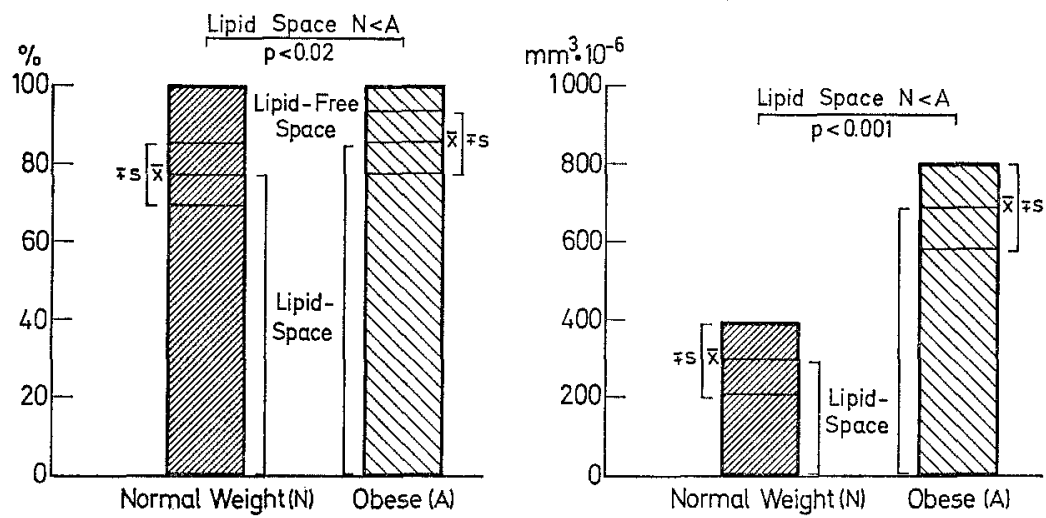

Fig. 2. Relative and absolute values for lipid space of isolated human adipocytes from normal weight and obese subjects
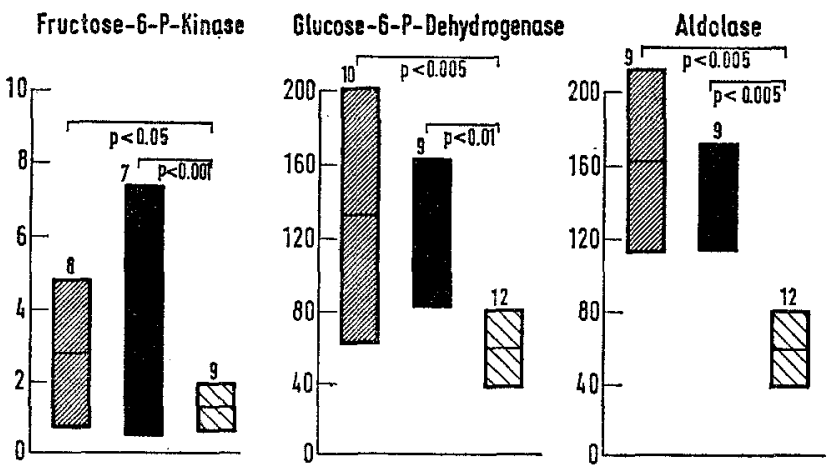

Hexose-P-Isomerose
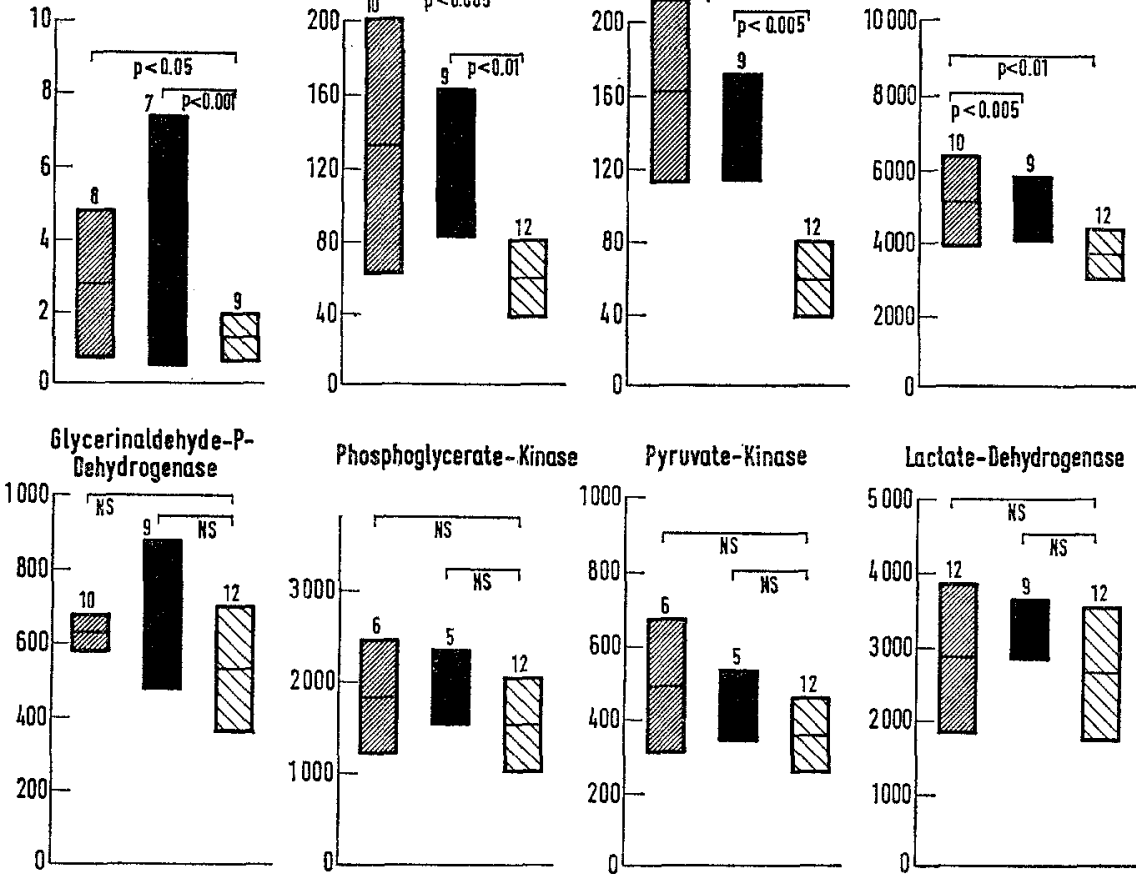

Group
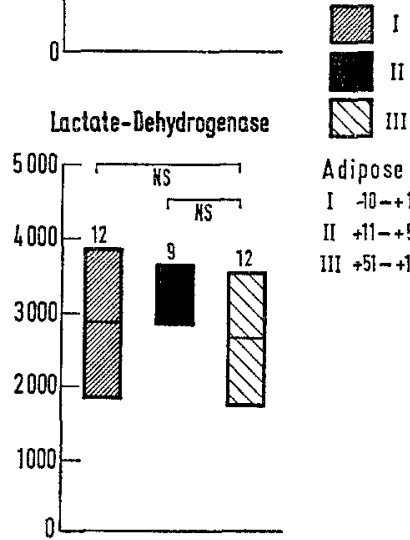

Adipose

I $-10-10 \%$

II $+11-+50 \%$

III $+51-+175 \%$

Fig. 3. Activities of enzymes of glycolysis and hexosemonophosphate-shunt in isolated human adipocytes from normal weight and obese subjects based on triglyceride content of fat cells. Obese: Group I from -10 to $+10 \%$ overweight; Group II from + 11 to $50 \%$; Group III from +51 to +175 overweight. Enzymes in isolated human fat cells from normal weight and obese subjects (in $\mu \mathrm{mol}$ Substrate metabolized $/ \mathrm{min} / \mathrm{mmol}$ Triglycerides) 
lipid-free space showed already that it is also enlarged in the adipocytes of obese subjects. The fat cell therefore does not only grow on account of storage, but also increase of its plasmatic substance. Nevertheless, the calculations showed that the lipid content of the cells increases more than the residual space, its proportion therefore being higher in obese than in normal weight subjects. For this reason these morphological changes which the fat cell undergoes during weight gain must induce a change in the components of its plasma space. It is also to be expected that the results depend on the reference system selected. In order to gain a better
But this value of $25 \%$ has been rather exceeded in some instances. The possibility that the enzyme content of the adipocyte is influenced by the phenomenon of induction can therefore not be ruled out.

The importance of the reference system for investigating adipose tissue has been stressed especially by Salans [23] and coworkers. They found that adipose tissue of obese subjects with enlarged cells showed less metabolic activity than that of normal weight subjects, but that its basal metabolic functions were normal if related to a defined number of cells. Nevertheless, the insulin effect on carbohydrate metabolism in adipocytes

Table 2. Calculation of regression lines and of the correlation coefficient for the logarithms of the enzymes G6PDH, HIM, PG/M, PGK, ALD, PK, GAPDH, LDH to the logarithm of overweight in $\%$

\begin{tabular}{|c|c|c|c|}
\hline Enzyme & Calculation of regression lines & $r$ & \\
\hline G6PDH & $\begin{array}{l}\delta \log y=-1.1619 \times \log x+4.5706 \\
O \log y=-1.0760 \times \log x+4.1983\end{array}$ & $\begin{array}{l}-0.479 \\
-0.529\end{array}$ & $\begin{array}{l}s \\
s\end{array}$ \\
\hline HIM & $\begin{array}{l}\hat{g} \log y=-1.2565 \times \log x+6.2253 \\
\stackrel{+}{\log y}=-0.5095 \times \log x+4.7156\end{array}$ & $\begin{array}{l}-0.572 \\
-0.520\end{array}$ & $s$ \\
\hline$\overline{\text { PG1M }}$ & $\begin{array}{l}\text { o } \log y=-1.3550 \times \log x+4.9210 \\
\text { \& } \log y=-0.8039 \times \log x+\mathbf{3 . 6 1 1 6}\end{array}$ & $\begin{array}{r}-0.398 \\
-0.237\end{array}$ & $\begin{array}{l}n s \\
n s\end{array}$ \\
\hline PGK & $\begin{array}{l}\hat{\circ} \log y=-0.2690 \times \log x+3.834 \\
\stackrel{+}{\log y}=-0.3744 \times \log x+4.0134\end{array}$ & $\begin{array}{l}-0.188 \\
-0.343\end{array}$ & $\begin{array}{l}n s \\
n s\end{array}$ \\
\hline ALD & $\begin{array}{l}\text { x log } y=-1.2348 \times \log x+4.7405 \\
+\log y=-0.6140 \times \log x+3.4049\end{array}$ & $\begin{array}{l}-0.616 \\
-0.519\end{array}$ & $\begin{array}{l}s \\
s\end{array}$ \\
\hline PK & $\begin{array}{l}\circ \log y=-0.9905 \times \log x+4.7213 \\
\stackrel{\log }{+} \log y=-0.5031 \times \log x+\mathbf{3 . 6 6 9 0}\end{array}$ & $\begin{array}{l}-0.428 \\
-0.477 \\
\end{array}$ & $\begin{array}{l}n s \\
n s\end{array}$ \\
\hline GAPDH & 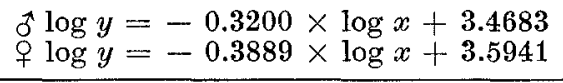 & $\begin{array}{r}-0.124 \\
-0.278 \\
\end{array}$ & $\begin{array}{l}n s \\
n s\end{array}$ \\
\hline $\mathrm{LDH}$ & $\begin{array}{l}\stackrel{x}{\log y}=-0.9978 \times \log x+5.5284 \\
\text { 잉 } \log y=-0.3212 \times \log x+4.1172\end{array}$ & $\begin{array}{r}-0.432 \\
-0.238\end{array}$ & $\begin{array}{l}n s \\
n s\end{array}$ \\
\hline
\end{tabular}

Calculated using the equations:

$\left.b=\frac{\Sigma(x y)-\bar{x} \Sigma y}{\Sigma x^{2}-\bar{x} \Sigma x} \quad a=y-b x \quad r=\frac{N \Sigma x y-\Sigma x \Sigma y}{\sqrt{\left(N \Sigma x^{2}-(\Sigma x)^{2}\right)\left(N \Sigma y^{2}\right)}}-(\Sigma y)\right)^{2}$

understanding of these questions, glycolytic enzymes in the adipocytes were investigated using different reference systems. Calculations of mean enzyme content of individual fat cells demonstrated that this is higher in obese than in normal weight subjects. If related to a defined fat cell mass we nevertheless found reduced enzyme activities in obesity corresponding to the procentual reduction of plasma space.

During evaluation of the data it became clear that the different enzymes do not behave similarly. In the individual cell the content of LDH and HIM was significantly elevated, whereas this increase was not present or insignificant for Aldolase and G6PDH. If increased enzyme activities resulted from an augmentation of the lipid-free space only, a proportionate increase would have to be expected. Thus it should be possible to calculate its extent from the data for the lipid-free space. Activities should be higher by about $25 \%$ in the cells of obese than in those of normal weight subjects. of obese people was reduced, there being a strong negative correlation of this reduction with fat cell size. We have also been able to demonstrate this diminished insulin sensitivity of adipose tissue during earlier studies (Kasperek et al. [14]; Berger et al. [1]). Since the enzyme content of adipocytes has been found reduced in obesity, one may assume that it is responsible for the limited metabolic capacity for glucose with insulin stimulation. However, other facts do not support this idea: The activities of the rate-limiting encymes Hexokinase and F6PK, calculated with several reference systems, are not significantly reduced (Englhardt et al. [7]), it therefore is not probable that they limit the amount of glucose metabolized.

Moreover, it has been shown that elevated medium glucose levels will stimulate glucose uptake of adipose tissue of normal weight and obese subjects much more than insulin (Reuter et al. [21]). Nevertheless, the extent of stimulation by high glucose concentrations 
$(400-600 \mathrm{mg} / 100 \mathrm{ml})$ was significantly lower in obesity than in normal weight persons. Therefore the possibility cannot be entirely excluded that the total glycolytic capacity is limited by the enzymatic equipment of the cell. It is unlikely though that this phenomenon is of any significance in the sense of a diminished metabolic capacity of the cell itself. It is presumably due to a changed morphological composition of the adipose tissue itself with preponderance of big lipid-rich adipocytes the plasma space of which is relatively reduced.

The metabolic picture of the fat cell in obesity is therefore essentially determined by the phenomena both of cell growth and storage. The abundance of lipids in these cells leads to a reduction of the plasmatic space of these cells which eventually will find its repercussions on adipose tissue in general. In spite of the increased amounts of enzyme in individual cells, the enzyme content of total adipose tissue must be diminished and the metabolic performance of this tissue will decrease with the development of overweight. No disturbances of enzyme activities corresponding to an inhibition have been shown in the adipocyte itself, on the contrary there are indications that adaptive metabolic processes will lead to an increased synthesis of certain enzymes in the enlarged adipocytes.

Acknowledgements. We thank the Deutsche Forschungsgemeinschaft and the Landesamt für Forschung des Landes Nordrhein-Westfalen for supporting our work. We are also grateful to our colleagues of the Chirurgische Universitätsklinik Düsseldorf for providing us with tissue material.

\section{References}

1. Berger, M., Gries, F.A., Herberg, L., Liebermeister, H.: Insulinempfindlichkeit des Glukosestoffwechsels und der Lipolyse im menschlichen Fettgewebe in vitro bei Adipositas mit und ohne Diabetes mellitus. Diabetologia in press.

1a. Bjurulf, P.: Atherosclerosis and body build with special reference to size and number of subcutaneous fat cells. Acta med. scand. Suppl. 349, 7 (1959).

2. Bücher, Th., Pette, Luh: Einfache und zusammengesetzte optische Tests mit Pyridinnucleotiden. In: Hoppe-Seyler-Thierfelder: Handbuch der phys.- und path.-chem. Analyse. Bd. VI A. Berlin, Göttingen, Heidelberg, New York: Springer.

3. Eggstein, M., Kreutz, F.H. : Eine neue Bestimmung der Neutralfette im Blutserum und Gewebe. I. Mitteilung: Prinzip, Durchführung, Besprechung der Methode. Klin. Wschr. 44, 262-267 (1966).

II. Mitteilung: Zuverlässigkeit der Methode andere Neutralbestimmungen, Normalwerte für Triglyceride und Glycerin im mensehlichen Blut. Klin. Wschr. 44, $267-273$ (1966).

4. Crofford, O.B., Renold, A.E.: Glucose uptake by incubated rat epidydimal adipose tissue, J. biol. Chem. 240, 14 (1965).

5. Englhardt, A., Hagemann, K., Jahnke, K.: Enzyme des energieliefernden Stoffwechsels im menschlichen Fettgewebe. Enzymol. biol. Clin. 9, 287 (1968).

6. - Gries, F.A., Preiss, H., Jahnke, K.: Vergleichende Untersuchungen über Protein- und Lipidgehalt und die Aktivitäten von Enzymen der Glycolyse und des 
Pentosephosphat-Shunts im Fettgewebe und in isolierten Fettzellen Stoffwechselgesunder. Hormon- und Stoffwechselforschung 1, 228(1969).

7. - Feld, Gries, F.A., Preiss, H.: (unpublished)

8. Entenman, C., Goldwater, W.H., Ayres, N.S., Behnke, A.R.: Analysis of adipose tissue in relation to body weight loss in man. J. appl. Physiol. 13, 129 (1958).

9. Folch, J.M., Lees, H.G., Sloane, S.: A simple method for the isolation and purification of total lipids from animal tissues J. biol. Chem. 225, 497 (1957).

10. Forbes, R.M., Cooper, A.P., Mitchell, H.H.: The composition of the adult human body as determined by chemical analysis. J. biol. Chem. 213, 359 (1953).

11. Hausberger, F.X., Hausberger, B.C.: Effect of insulin and cortisone on weight gain protein and fat content of rats. Amer. J. Physiol, 193, 455 (1958).

12. Hirsch, J., Goldrick, R.B.: Serial studies on the metabolism of human adipose tissue, I. Lipogenisis and free fatty acid uptake and release in small aspirated samples of subcutaneous fat. J. clin. Invest. 43, 1776 (1964).

13. Jahnke, K., Herberg, M.: Zur Methode der Neutralfettbestimmung im Serum (Enzymatischer GlyceridGlycerin-Nachweis). Das ärztliche Laboratorium 15, 201 (1969).

14. Kasperek, R., Englhardt, A., Liebermeister, H., Jahn$\mathrm{ke}$, K.: In vitro-Untersuchungen über die Glucoseaufnahme des menschlichen Fettgewebes bei Normgewichtigen und Adipösen. Vortrag 4. Kongress Dtsch. Diabetes-Ges., Ulm 1969.

15. Liebelt, R.A.: Response to adipose tissue in experimental obesity as influenced by genetic, hormonal and neurogenic factors. Ann. N.Y. Acad. Sci. 110, $723(1963)$.

16. Mandle, J., Mc. Lennan, I.D., Howes, E. L.: Isolation and characterisation of proteinase and collagenase from Cl. histolyticum J. clin. Invest. 32, 1323 (1953).

17. Mitchell, H.H., Hamilton, T.S., Steggerda, F.R., Bean, H.W.: The chemical composition of the adult human body and its bearing on the biochemistry of the growth. J. biol. Chem. 158, 625 (1945).

18. Morse, W.T., Soeldner, S.: The measure of human adipose tissue mass. Handbook of Physiol., Section 5. Adipose tissue, p. 653. Washington: 1965.

19. Pawan, G.L.S., Close, M.: The gross chemical composition of the subcutaneous adipose tissue in the lean and obese human subject. Biochem. J. 74, 90 (1960).

20. Preiss, H., Hesse-Wortmann, Ch., Gries, F.A., Jahnke, K.: Die Größe menschlicher isolierter Fettzellen in Abhängigkeit vom Ernährungszustand. Vortragstagung Dtsch. Ges. Wissenschaften, Mainz, 1967.

21. Reuter, Englhardt, A., Liebermeister, H., Jahnke, K. : to be published.

22. Rodbell, M. : Metabolism of isolated fat cells. J. biol. Chem. 239, 375 (1964).

23. Salans, L.B., Knittle, J.L., Hirsch, J.: The role of cell size and adipose tissue insulin sensitivity in the carbohydrate intolerance of human obesity. J. clin. Invest. 47, 153 (1968).

Prof. Dr. A. Englhardt

Med. Univ.-Klinik

BRD-3550 Marburg/Lahn

Mannkopffstr. 1

Deutschland 